\title{
AN INTEGRATED VIEW: NEUROADIPOCRINOLOGY OF DIABESITY
}

George N. Chaldakov ${ }^{1}$, Marco Fiore ${ }^{2}$, Gorana Ranćić ${ }^{3}$, Jerzy Beltowski ${ }^{4}$, Neșe Tunçel ${ }^{5}$, and Luigi Aloe ${ }^{2}$ ${ }^{1}$ Laboratory of Cell Biology, Department of Anatomy and Histology, Medical University, Varna, Bulgaria, ${ }^{2}$ Institute of Cellular Biology and Neurobiology, National Research Council (CNR), Rome, Italy, ${ }^{3}$ Department of Histology and Embryology, University Medical Faculty, Niš, Serbia, ${ }^{4}$ Department of Pathophysiology, Medical University, Lublin, Poland,

${ }^{5}$ Department of Physiology, Medical Faculty, Eskişehir Osmangazi University, Eskişehir, Turkey

\section{INTEGRISANI PRIIAZ: NEUROADIPOIRINOLOGIJA DIABESITY (DIJABETES TIP 2 UDRUŽEN SA GOJAZNOŠĆU)}

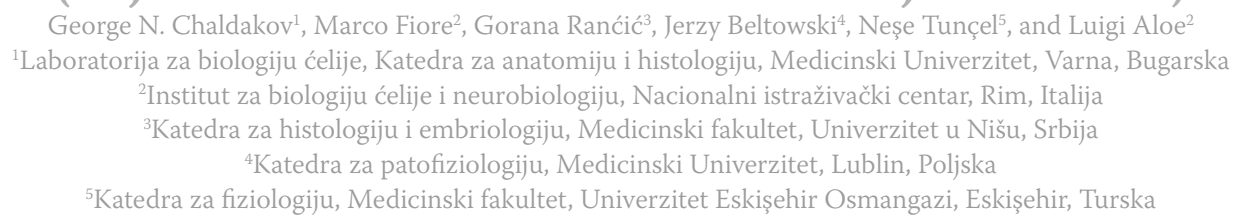

\section{ABSTRACT}

Today's achievements in systems biology and -omics sciences have facilitated a shift from studying individual molecules and tissues to characterising molecules and cells holistically. In this article, we attempt to discuss the status of a much-needed coherent view that integrates studies on neurobiology and adipobiology, as well as those on diabetes and obesity. Globally, cardiometabolic diseases (atherosclerosis, hypertension, type 2 diabetes mellitus, obesity, diabesity, and metabolic syndrome) are the most prevalent pathologies. In 2000, Astrup and Finer (Obes Rev 1: 57-59) wrote the following: "Since type 2 diabetes is obesity dependent, and obesity is the main aetiogical cause of type 2 diabetes, we propose the term 'diabesity' should be adopted." Arguably, the research field of adipobiology has witnessed three major paradigm shifts since the discovery of leptin, an adipose-derived hormone, in 1994. Various neuroendocrine and neurotrophic factors are included in the growing list of endocrine and paracrine adipose-secreted signaling proteins collectively designated adipokines. These findings open a novel field of research known as neuroadipocrinology, a component of neuroendocrinology. Adipokines, including nerve growth factor $(N G F)$ and brain-derived neurotrophic factor (BDNF), mediate multiple biological processes, such as food intake, immunity, inflammation, memory, mood, and metabolism. The effects on metabolism involve the maintenance of glucose, lipid and energy homeostasis as well as cardioprotection, neuroprotection, and aging. In this article, we highlight the role of metabotrophic factors (MTF) and the adipose- and nonadipose-derived biomolecules that mediate these effects. Recent results demonstrate that circulating and tissue levels of certain MTFs, e.g., adiponectin, NGF, BDNF, glucagon-like protein-1, sirtuin-1, interleukin-10, and aquaporin-7, are altered in cardiometabolic diseases, including diabesity. Overall, this may cultivate

\section{SAŽETAK}

Današnja dostignuća u biologiji sistema i povezanim biološkim naukama omogućila su prelazak sa proučavanja pojedinačnog molekula i tkiva na holistički prikaz molekula i ćelija. Ovde pokušavamo da objasnimo koherentan prikaz koji integriše studije neurobiologije i adipobiologije, kao $i$ one o dijabetesu i gojaznosti. Uopšteno, kardiometaboličke bolesti (ateroskleroza, hipertenzija, dijabetes melitus tip 2, gojaznost, diabesity (dijabetes melitus tip 2 udružen sa gojaznošću), i metabolički sindrom) predstavljaju najčešća oboljenja današnjice. 2000. godine Astrup i Finer (Obes Rev 1: 57-59) su napisali: "Obzirom da dijabetes melitus tip 2 zavisi od gojaznosti, a gojaznost je glavni etiološki uzrok dijabetesa tip 2, predlažemo da se termin 'diabesity' usvoji." Verovatno je polje istraživanja adipobiologije svedočilo o tri velike promene od otkrića leptina, hormona adipoznog porekla, 1994.godine. Različiti neuroendokrini i neurotrofični faktori su takođe bili uključeni u povećanje liste endokrinih $i$ parakrinih signalnih proteina sekretovanih od strane adipocita koji zajedno cine adipokine. Ovi nalazi otvaraju novu oblast istraživanja, neuroadipokrinologiju, deo neuroendokrinologije. Adipokini, uključujući faktor rasta nerava (NGF) i neurotrofični faktor poreklom iz mozga (BDNF), posreduju u višestrukim biološkim procesima kao što su unos hrane, imunitet, inflamacija, pamćenje, raspoloženje i metaboliza. Efekti na metabolizam uključuju održavanje glukoze, lipida i energetske homeostaze, kao $i$ kardioprotekciju, neuroprotekciju i starenje. Ovde izdvajamo ulogu metabotropnog faktora (MTF), biomolekula poreklom iz masti, kao i biomolekula koji ne vode poreklo iz masti, koji posreduju ove efekte. Nedavni rezultati pokazuju da se cirkulišući i/ili tkivni nivoi nekog MTF, na primer adiponektin, NGF, BDNF, glukagonu sličan protein-1, sirtuin-1, interleukin-10, akvaporin-7, menjaju u kardiometaboličkim bolestima, uključujući diabesity. Uopšteno, ovo može otvoriti nov pristup u razmišljanju o dijabetesu tip 2 
a novel thinking for diabesity, herein also referred to as Homo diabesus.

Key words: adipobiology, adipokines, diabetes, obesity, neurobiology, NGF, BDNF, metabotrophins udruženim sa gojaznošću, koji se takođe ovde označava kao $i$ Homo diabesus.

Ključne reči: adipobiologija, adipokini, dijabetes, gojaznost, neurobiologija, NGF, BDNF, metabotrofini.

\section{ABBREVIATIONS \\ AD-Alzheimer's disease AQP-aquaporin \\ BAT-brown adipose tissue BDNF-brain-derived neurotrophic factor MTF-metabotrophic factor \\ NGF-nerve growth factor \\ NT-neurotrophin \\ PPAR-peroxisome proliferator-activated receptor \\ Trk-tropomyosin-related kinase/receptor tyrosine kinase UCP-uncoupling protein WAT, white adipose tissue}

Thus, the task is not so much to see what no one has yet seen, but to think what nobody has yet thought about that which everybody sees.

\section{INTRODUCTION}

In the second half of the 20th century, holism (from the Ancient Greek word holos, meaning whole, entire, or total) led to thinking in terms of systems and their derivatives, such as systems biology. Life at both the local and systemic levels requires nutritional, immune, neurotrophic and metabotrophic support. Any dysfunction of or deficit in this support may result in a disease phenotype, such as type 2 diabetes or obesity, or a combination of the two, diabesity.

Type 2 diabetes mellitus is largely responsible for the prediction that the number of diabetics worldwide will double within a period of 30 years, increasing from 150 million people in 1995 to over 300 million by 2025 (1).

At its core, obesity may be briefly classified as the accumulation and inflammation of adipose tissue (Fig. 1), and the adipose-derived pro-inflammatory signals are disseminated to many organs of the body, leading to the subsequent development of cardiometabolic and neurodegenerative diseases (the scope of the present short review), as well as non-alcoholic steatohepatitis, polycystic ovarian

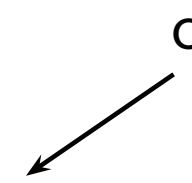

Fat accumulation

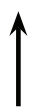

Energy balance

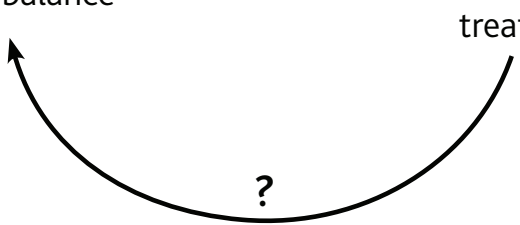

Figure 1. A drawing showing an oversimplified view of the possible pathogenesis of and therapies for obesity.
Arthur Schopenhauer

syndrome, obstructive sleep apnoea, inflammatory bowel disease, thyroid-associated ophthalmopathy, cancer and many other diseases outside the scope of present review.

Obesity is the most prevalent disease in the world. In 2005, 800 million people were overweight (BMI $25.0-29.9 \mathrm{~kg} / \mathrm{m}^{2}$ ), and 400 million were obese (BMI over $\left.30 \mathrm{~kg} / \mathrm{m}^{2}\right)(1)$. Although the pathogenesis of obesity is not yet completely understood, there is now solid evidence that type 2 (non-insulin dependent) diabetes is strongly associated with the obese man (Homo obesus) (2). Therefore, diabesity (3) or Homo diabesus (4) has moved to centre stage as one of the most challenging biomedical and social threats, with its rising prevalence and impacts on both health and economics, in the present century. The health impact of diabesity includes a reduction of both quality of life and life expectancy due to complications such as myocardial infarction, stroke and end-stage renal disease. The burden of diabetes on the world economy has been rising in the last decade, as costs reached 376 billion dollars in 2010 and are expected to reach 490 billion dollars by 2030 (3). These latter authors wrote: "This century is the unprecedented diabetogenic era in human history. It is thus urgent to take steps including screening, prevention and early management in an attempt to control this evolving epidemic of diabesity." Furthermore, there is an "interaction" between diabesity and Alzheimer's disease, which will be highlighted below.

\section{Adipobiology: a field marked by three paradigm shifts}

One of biggest recent advances in studying cardiovascular diseases is associated with the "rediscovery" of a neglected tissue, adipose tissue.

In 1962, Thomas S. Kuhn published his book The Structure of Scientific Revolutions (1st edition, University of Chicago Press, Chicago, USA). Its publication was 
Table 1. A paradigm shift: never before has adipose tissue been so active

\section{FROM}

Adipose tissue is a lipid and energy

storage and is involved in obesity

TO

Adipose tissue is an endocrine and paracrine organ

Adipose tissue is a neuroendocrine organ

Adipose tissue is a steroidogenic organ

Adipose tissue is an immune organ

Adipose tissue is a source of and target for

inflammatory mediators

Adipose tissue produces all components of

the rennin-angiotensin system

Adipose tissue is therefore involved in

numerous diseases beyond obesity

a landmark event in both the history and philosophy of scientific knowledge (epistemology). Kuhn challenged the then prevailing view of "normal science," which was viewed as "development-by-accumulation" of accepted facts and concepts leading often to epistemological paralysis, or neophobia. Kuhn argued for a model in which a period of such conceptual continuity in normal science was interrupted by a period of revolutionary science, leading to a new paradigm, an event he designated the paradigm shift.

At an epistemological level, adipose tissue has undergone three major paradigm shifts in the last 20 years, and has risen above the horizon and taken centre stage in a number of syndromes and that astonishes most scientists and medical doctors.

The first paradigm shift says: while considered as passive storage-release of lipids by most cell biologists and pathologists for a long period of time, adipose tissue is now considered the biggest endocrine and paracrine organ of the human body (Table 1). The discovery of leptin, an adipose-secreted hormone, published on 1 December 1994 in Nature 1994, 372:425-432 by Jeffrey Friedman and colleagues, marked this revolutionary event. This discov-

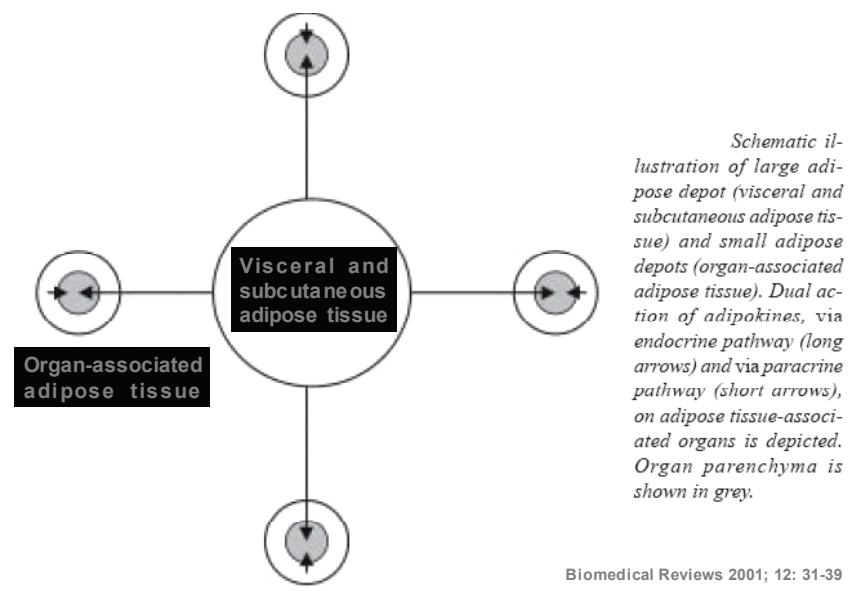

Figure 2. As indicated above/right.

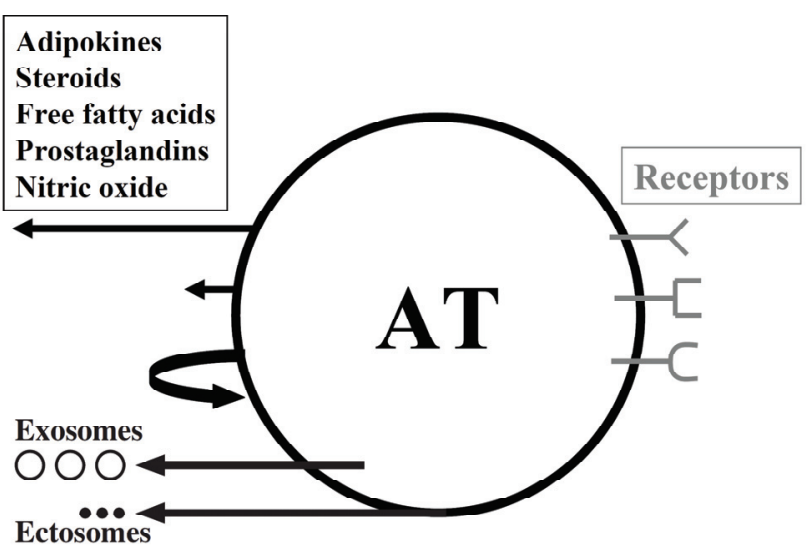

Figure 3. A drawing illustrating both the secretory and receptor nature of adipose tissue (AT) cells. At the secretory level, AT-derived signaling molecules communicate via multiple pathways, such as endocrine (arrows 1, 4 and 5, from top to bottom), paracrine (arrow 2) and autocrine (arrow 3, curved) pathways. Also depicted is that AT cells express receptors for various ligands. From (24).

ery was based on the pioneering contributions of Douglas Coleman (1931-2014). His work established the first clues regarding a genetic component to obesity. In the 1970s, Coleman conducted a series of experiments that led him to propose the existence of a satiety factor that would account for the development of obesity and type 2 diabetes among laboratory mice.

The second paradigm shift derived from a study by Jeffrey Bell and colleagues (5), who have scanned nearly 800 people with magnetic resonance imaging (MRI) to obtain a map of white adipose tissue (WAT). The authors demonstrated that as many as 45 percent of women and nearly 60 percent of men have normal body mass index (BMI, 20-25 $\mathrm{kg} / \mathrm{m}^{2}$ ) scores and appear thin outside (TO), but actually have excessive levels of internal adipose tissue:, i.e., they are fat inside (FI). Therefore, they have the TOFI phenotype of body fat. The TOFI phenotype was also found among professional models. TOFI may therefore be considered an, "invisible" expression of both Homo obesus (2) and Homo diabesus (4).

The third paradigm shift features the increasing significance of brown adipose tissue (BAT) in both health and disease (see below).

Accumulation of adipose tissue in visceral and subcutaneous abdominal tissue, as well as near internal organs (Fig. 2 ), is a major risk factor for the development of numerous disorders, including diabesity and other related diseases. Metaflammation (metabolically induced inflammation) has emerged as a pivotal process in these disorders (6).

Adipose tissue is very plastic tissue and is constantly remodelled with weight gain and weight loss. It is a dynamic cellular and extracellular matrix assembly of adipocytes, fibroblasts, immune cells and matrix components and is also rich in sympathetic nerve fibres, blood vessels, and stem cells. There are two major subtypes of adipose tissue, WAT and BAT.

By sending and receiving different types of protein and non-protein signals, adipose tissue communicates with 
many organs in the body (Fig. 3), therefore contributing to the control of energy, lipid and glucose homeostasis, as well as inflammation, immunity, learning and memory, among other biological functions.

In the human body, WAT stores energy and BAT dissipates energy by producing heat. BAT-mediated increases in energy expenditure are realised by uncoupling respiration from ATP synthesis via uncoupling protein 1 (UCP1), which is expressed in brown adipocytes, subsequently generating heat, a process known as adaptive thermogenesis. Animal studies have shown that the activation of BAT counteracts the effects of diet-induced weight gain and related disorders such as type 2 diabetes and metabolic syndrome: this may also be the case in humans (7). Recently, knowledge regarding WAT and BAT was enriched by information about their relatives, namely brite (brown in white) and bruscle (brown in skeletal muscle) adipocytes (8). Hence, brown adipobiology is emerging as a new focus in biomedicine.

In effect, such an adipocentric approach has revealed that although BAT is major thermogenic organ, whereas WAT is the body's largest endocrine and paracrine organ and produces multiple signaling proteins, which are collectively termed adipokines (9-12). Nerve growth factor (NGF) and brain-derived neurotrophic factor (BDNF) are also produced by both WAT and BAT (13).

\section{Multifunctionality of neurotrophins and adipokines}

At the end of the 19th century it was envisaged by Santiago Ramon y Cajal but has not been proved that the nerves require trophic support, an idea that has never been proven. The proof was obtained through a rare combination of scientific reasoning and intuition by Rita Levi-Montalcini (1909-2012) in the early 1950s, in Saint Louis, MO, USA, when the first cell growth factor, NGF, was discovered. Levi-Montalcini was awarded the Nobel Prize in Medicine or Physiology 1986. The discovery of NGF has been embodied in a conceptual framework known as the neurotrophic theory. It reveals a pivotal role of effector (target) cells in the control of neuronal differentiation, survival and function via the production of NGF and other neurotrophic factors (14).

The neurotrophin family of proteins consists of NGF, BDNF, neurotrophin-3 (NT-3), NT-4/5, NT-6, and NT-7. Neurotrophins mediate their effects via ligation of (i) the panneurotrophin receptor, p75 $5^{\mathrm{NTR}}$, and (ii) the receptor tyrosine kinases (tropomyosin-related kinase) (Trk), TrkA (for NGF), TrkB (for BDNF and NT-4), and TrkC (for NT-3) (reviewed in 12,14,15).

The past three decades have witnessed a number of breakthroughs regarding Rita Levi-Montalcini's NGF. Studies have revealed that NGF and BDNF not only are stimulators of nerve growth and survival but they also exert trophic effects on (i) immune cells, acting as immunotrophins; (ii) keratinocytes, enterocytes, and prostate and breast epithelial cells, acting as epitheliotrophins; and (iii) endothelial cells, acting as angiogenic factors (reviewed in 12,14-15).

\section{From neurotrophins to metabotrophins}

In 2003, additional phenotypic expressions of NGF were revealed, including metabotrophic actions on glucose, lipids, energy, pancreatic beta cells and cardiovascular homeostasis, and subsequently designated (analogous to neurotrophic factors and neurotrophins) as metabotrophic factors (MTF) or metabotrophins (from the Greek words metabole and trophe, meaning "nutritious for metabolism") (12,15-18), a family to which BDNF also belongs. The proof-of-hypothesis was based on results demonstrating that circulating and tissue levels of both NGF and BDNF are (commonly) decreased in atherosclerosis, metabolic syndrome (19), type 2 diabetes (20) and Alzheimer's disease (15), which currently is considered type 3 diabetes (21).

\section{Neuroadipocrinology}

As a multiplex of biological systems, life requires an interaction between its molecular and cellular components. One of the biggest recent achievements of neurobiology and adipobiology is the studies on neurotrophic factors (e.g., NGF and BDNF) and adipokines (e.g., leptin and adiponectin).

As often occurs, the framework of an initial concept of the physiological role of a newly discovered molecules extends in the light of emerging findings. This was the case with neurotrophic factors and adipokines. For instance, in the more than 30 years following the discovery of NGF, there have been few indications that it acts on non-neuronal cells. Therefore, it was remarkable when Aloe and Levi-Montalcini discovered that treatment of newborn rats with NGF caused a systemic increase in mast cells, in 1977. This seminal finding paved the way for a novel research field, neuroimmunology (22, 23 and references therein).

As indicated above (9-13), WAT is a dynamic endocrine and paracrine organ, producing a large number of adipokines. Some of them, e.g., leptin, mediate cross-talk between adipose tissue and the hypothalamus in regulating food intake and energy expenditure. However, the hypothalamus is not the only brain target for leptin, and the regulation of food intake is not this adipokine's only biological action. Rather, some adipokines support various cognitive functions and have neurotrophic activity. Current data regarding adiposederived neuroendocrine and neurotrophic factors are summarised in Tables 2 and 3. This finding raises an intriguing question as to whether WAT may be a peripheral counterpart of the hypothalamus-hypophysis axis. Cumulatively, linking neurobiology and adipobiology resulted in neuroadipology (24), herein renamed neuroadipocrinology. 
WAT
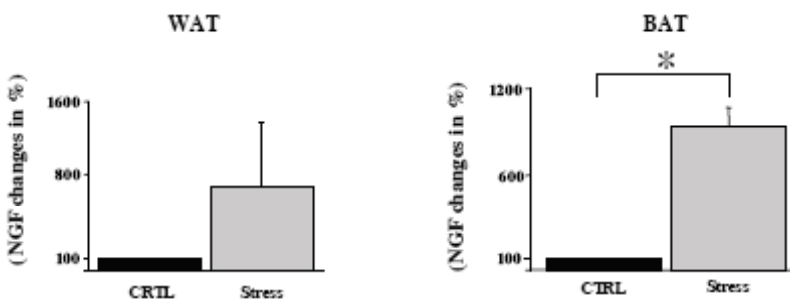

WAT
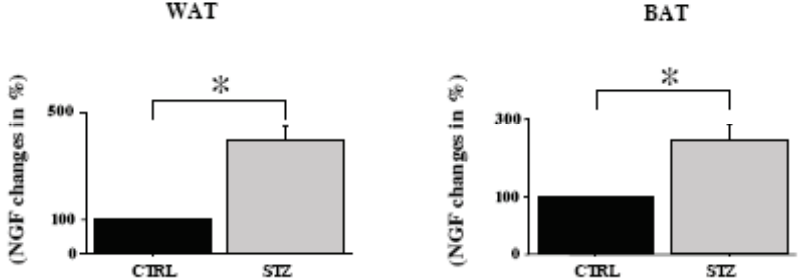

Figure 4. Changes in the amount of nerve growth factor (NGF) in white adipose tissue (WAT) and brown adipose tissue (BAT) of controls (CTRL) compared to the concentration of NGF in stressed mice (Stress) and streptozotocin-induced diabetic rats (STZ), expressed as a percentage of the controls. Note the enhanced presence of NGF in WAT and BAT in stressed mice, as well as in diabetic rats. The vertical lines in the figure indicate pooled S.E.M. derived from the appropriate error mean square in the ANOVA. * Significant differences between groups ( $\mathrm{p}<0.05)$. From (13).

In an attempt to "close" the metabotrophic "loop" in cardiometabolic disease, we have measured circulating levels of NGF and BDNF in patients with acute coronary syndrome, and found that they are significantly reduced (25, cf. 26). Another study revealed altered levels of NGF in the pancreas and brain in streptozotocin-induced diabetes (27). Recently, it was demonstrated that in response to experimental stress or diabetes, the amount of NGF and BDNF was altered both in WAT and BAT (Fig. 4,5); for mast cells see Figure 6.

Table 2. Selected list of adipose-derived neuroendocrine factors

Neuropeptides
Neuropeptide tyrosine (NPY)
Substance P
Calcitonin gene-related peptide
Agouti-related protein
Adrenomedullin
Somatostatin
Kisspeptin
Neuromedin B
Neurotensin
Apelin
Nesfatin-1
Hypothalamic factors
Mineralocorticoid-releasing factors
Corticotropin-releasing hormone (CRH)
Stresscopin, urocortin (CRH-like peptides)
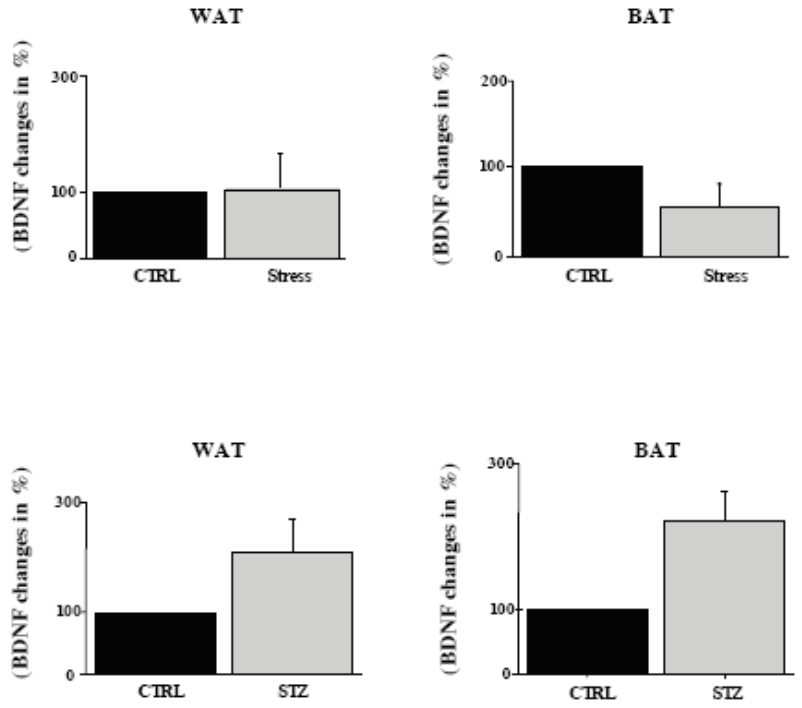

Figure 5. Changes in the amount of brain-derived neurotrophic factor (BDNF) in epicardial white adipose tissue (WAT) and brown adipose tissue (BAT) of controls (CTRL) compared to the concentration of BDNF in stressed mice (Stress) and in streptozotocin-induced diabetic rats (STZ), expressed as a percentage of the controls. The vertical lines in the figure indicate pooled S.E.M. derived from the appropriate error mean square in the ANOVA. From (13).
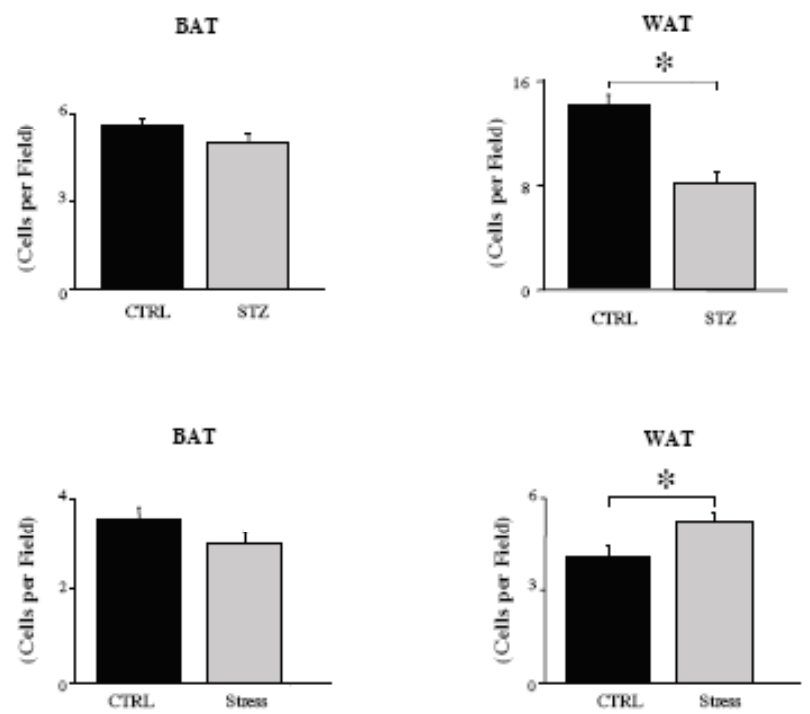

Figure 6. Changes in the number of mast cells in brown adipose tissue (BAT) and epicardial white adipose tissue (WAT) of controls (CTRL) compared to streptozotocin-induced diabetic rats (STZ) and stressed mice (Stress), expressed as a percentage of the controls. The vertical lines in the figure indicate pooled S.E.M. derived from the appropriate error mean square in the ANOVA.

\section{PERSPECTIVE}

Examples of proof-of-metabotrophic hypothesis derived from other laboratories include the following: (i) pancreatic beta cells secrete NGF and express its receptor TrkA, findings implicated in the pathogenesis of diabetes mellitus (28), and (ii) mutations affecting the Bdnf gene 
Table 3. Selected list of adipose-derived neurotrophic factors

\section{Leptin}

Nerve growth factor

Brain-derived neurotrophic factor

Angiopoietin-1

Vascular endothelial growth factor

Ciliary neurotrophic factor

Glial cell line-derived neurotrophic factor

Steroids

Metallothioneins

(encoding BDNF) in mice or the Ntr $2 k 2$ gene (encoding the high-affinity BDNF receptor TrkB) in humans are associated with hyperphagia and severe obesity (15 and references therein). Lists of selected metabotrophins (Table 4) and the metabotrophic effects of NGF and BDNF (Table 5) are provided in the aforementioned tables.

In this context, the recent discovery of (i) humanin, a mitochondria-derived peptide expressing neuro-metabotrophic effects (29,30), and (ii) irisin, a myokine/ adipokine involved in the browning of WAT $(31,32)$, may lead to the development of a novel approach in therapy for Homo diabesus. It may open new paths in the search for exogenous MTF, such as (i) small molecules that boost the secretory or signaling pathways of MTF (15) and (ii) incretin mimetics and receptor agonists, because the insulinotropic hormone, glucagon-like peptide-1 (GLP-1), and exendin-4, a GLP-1 receptor agonist, exert neurometabotrophic effects $(33,34)$. Furthermore, (i) transgenic mice with Alzheimer's disease fed J147, a new compound, demonstrate improved memory, a finding correlated with reduced soluble levels of beta-amyloid and increased hippocampal levels of NGF and BDNF, in addition to the

Table 4. Selected list of endogenous metabotrophic factors*

\section{Secretory proteins}

Nerve growth factor, Brain-derived neurotrophic factor Ciliary neurotrophic factor, Neuron-derived neurotrophic factor

Adiponectin, Irisin, Humanin, Omentin, Chemerin, Apelin, Otopetrin 1

Interleukin-10, Interleukin-1 receptor antagonist, Metalothioneins

Glucagon-like peptide-1

\section{Intracellular proteins}

Sirtuin-1, PPAR-gamma, Uncoupling protein-1 (UCP-1) Aquaporin- $7 * \%$

\footnotetext{
* Modified from (12). For references, see the text, and also (43-55).

**:Discovered in 1986 by Gheorghe Benga (56) as the water channel integral membrane protein, in erythrocytes, the family of proteins designated the aquaporins (AQP) was appreciated when the Nobel Prize in Chemistry was awarded in 2003 to Peter Egre, whereas its original discovery by Gheorghe Benga has been ignored. Today, the AQP family consists of more than 10 members, AQP7 being expressed in adipocytes and related to obesity $(57,58)$.
}

Table 5. Metabotrophic effects of NGF and BDNF*

NGF shares homology with proinsulin

NGF and BDNF are produced by pancreatic beta cells and exert insulinotropic effects

NGF and BDNF are trophic factors for pancreatic beta cells, and also improve beta cell transplantation

NGF up-regulates the expression of LDL receptor-related protein

NGF up-regulates the expression of PPARgamma

NGF inhibits glucose-induced down-regulation of caveolin-1

NGF improves skin and corneal wound healing

NGF may improve vascular (atheroma) wound healing

NGF rescues silent myocardial ischemia in diabetes mellitus

NGF improves diabetic erectile dysfunction

NGF and BDNF suppress food intake

Healthy lifestyle increases brain and circulating levels of NGF and BDNF

An atherogenic diet decreases brain BDNF levels

BDNF-deficient mice develop abnormalities similar to metabolic syndrome

BDNF improves cognitive processes

Modified from (15). For references, see the text, and also 36, 39, 47, 48, $50-53,66,67$.

BDNF-responsive synaptotrophic proteins Homer-1 and Egr3 (35): (ii) an ATP-NGF complex, but not NGF itself, appears to be the active neuroprotective mediator (36): (iii) NGF is related to enhanced expression of the purinergic $\mathrm{P} 2 \mathrm{X}(3)$ receptor (37): (iv) metformin, a widely prescribed drug for type 2 diabetes, may exert neuroprotective effects by increasing BDNF levels (38), and (v) vitamin A may exert antidiabetic effects via NGF expression (39). Likewise, the role of microRNA in diabetes development has been recognised (40, also see 41 and 42 for sirtuin-1). A possible therapeutic pathway for the management of diabesity is shown in Figure 7.

The present integrated view also suggests that understanding the precise role of MTF in the origin of Homo diabesus may lead to new therapies for diabesity and related diseases, including Alzheimer's disease (AD). The use of transcript clustering to identify molecular mecha-

\section{PATHWAYS}

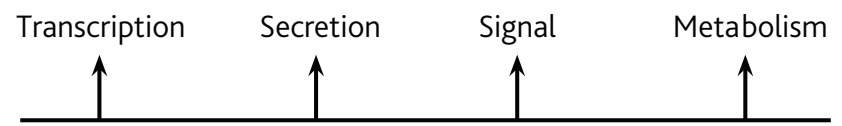

Pharmaceuticals, Nutraceuticals, Xenohormetics, Calorie restriction mimetics, Incretin mimetics ...

Figure 7. A drawing presenting a possible therapeutic pathway for diabesity. 
nisms contributing to the early stages of AD in mice has identified changes in the insulin signaling pathway, including the down-regulation of insulin receptor substrate 4 (Irs4), an early event in AD (59). Insulin and MTF signaling are strongly associated with diabesity, which has recently been identified as a potential risk factor for $\mathrm{AD}$ (60-66; also see 67).

\section{CONCLUSION}

In 1999, Albee Messing published in an editorial entitled "Nestin in the liver - lessons from the brain" in Hepatology (29: 602-603). He wrote the following: "Most neuroscientists manage to get through each day without thinking of the liver even once... but I think that is about to change." This may also be the case for adipose tissue. Future new thinking in neuroadipocrinology of diabesity may lead to a deeper insight about how we can make MTF secretion and signaling work for the improvement of physical and mental quality of life of Homo diabesus who is expressing now in more than a trillion earthians.

\section{ACKNOWLEDGEMENTS}

None of this review article would have been possible without the staunch support and creative collaboration of our brain-and-heart friends (BHF), Peter Ghenev, Anton B. Tonchev, Francesco Angelucci, Marcia Hiriart, Danko Georgiev, Pepa Atanassova, Stanislav Yanev, and many others. We apologise to the authors who were not quoted in this text, as their work was omitted for the sake of brevity.

\section{REFERENCES}

1. Williams G, Frühbeck G. Obesity: Science to Practice. 2009 John Wiley \& Sons, Ltd, UK.

2. Chaldakov GN, Fiore M, Tonchev AB, Dimitrov D, Pancheva R, Rančič G, Aloe L. Homo obesus: a metabotrophin-deficient species. Pharmacology and nutrition insight. Curr Pharm Des 2007; 13: 2176-2179.

3. Farag YM, Gaballa MR. Diabesity: an overview of a rising epidemic. Mephrol Dial Transplant 2011;26:28-35. doi: $10.1093 /$ ndt/gfq576

4. Aloe L, Tonchev AB, Fiore M, Chaldakov GN. Homo diabesus: involvement of metabotrophic factors. Adipobiology 2013; 5: 45-49.

5. Louise TE, Saeed N, Hajnal JV, Brynes A,Goldstone AP, FrostG, et al. Magnetic resonance imaging of total body fat. J Appl Physiol 1998; 85: 1778-1785.

6. Jin C, Flavell RA. Innate sensors of pathogen and stress: linking inflammation to obesity. J Allergy Clin Immunol 2013; 132:287-294. doi:10.1016/j.jaci.2013. 06.022.

7. Sacks H, Symonds ME. Anatomical locations of human brown adipose tissue functional relevance and impli- cations in obesity and type 2 diabetes. Diabetes 2013; 62:1783-1790.

8. Giralt M, Villarrova F. White, brown, beige/brite: different adipose cells for different functions? Endocrinology 2013; 154:2992-3000. doi: 10.1210/en.2013-1403.

9. Chaldakov GN, Stankulov IS, Hristova M, Ghenev PI. Adipobiology of disease: adipokines and adipokinetargeted pharmacology. Curr Pharm Des 2003; 9: 1023-1031.

10. Chaldakov GN. Cardiovascular adipobiology: a novel. Heart-associated adipose tissue in cardiovascular disease. Ser J Exp Clin Res 2008; 9:81-88.

11. Renes J, Mariman E. Application of proteomics technology in adipocyte biology. Mol Biosyst 2013; 9:1076-1091.

12. Chaldakov GN, Tonchev AB, Fiore M, Hristova MG, Pancheva R, Rancic G, Aloe L. Implication for the future of obesity management. In: G. Fruhbeck, editor. Peptides in Energy Balance and Obesity. CAB International 2009; pp 369-389.

13. Sornelli F, Fiore M, Chaldakov GN, Aloe L. Adipose tissue-derived nerve growth factor and brain-derived neurotrophic factor: results from experimental stress and diabetes. Gen Physiol Biophys 2009; 28:179-183.

14. Levi-Montalcini R. The nerve growth factor 35 years later. Science 1987; 237:1154-1162. doi:10.1126/science.3306916

15. Yanev S, Aloe L, Fiore F, Chaldakov GN. Neurotrophic and metabotrophic potential of nerve growth factor and brain-derived neurotrophic factor: Linking cardiometabolic and neuropsychiatric diseases. World J Pharmacol 2013; 2: 92-99. doi:10.5497/wjp.v2.i4.92.

16. Chaldakov GN. The metabotrophic NGF and BDNF: an emerging concept. Arch Ital Biol 2011;149: 257-263.

17. Gomez-Pinilla F, Vaynman S, Ying Z. Brain-derived neurotrophic factor functions as a metabotrophin to mediate the effects of exercise on cognition. Eur $J$ Neurosci 2008; 28: 2278-2287. doi: 10.1111/j.1460-9568 .2008.06524.x

18. Hiriart-Urdanivia M, Tableros VN, Velasco M, Larqué C, Cabrera-Vásquez S, Soto CS, et al. Insulin regulation in development and obesity. In: M. Hiriart-Urdanivia and J. Mas-Oliva, editors. Advances in Obesity-diabetes Research at UNAM (Universidad Nacional Autónoma de México). Manual Moderno, México D.F., Bogotá, DC. 2010; pp 69-79.

19. Chaldakov GN, Fiore M, Stankulov IS, Manni L, Hristova MG, Antonelli A, et al. Neurotrophin presence in human coronary atherosclerosis and metabolic syndrome: a role for NGF and BDNF in cardiovascular disease? Prog Brain Res 2004; 146: 279-289. doi: 10.1016/ S0079-6123(03)46018-4

20. Yamanaka M, Itakura Y, Ono-Kishino M, Tsuchida A, Nakagawa T, Taiji M. Intermittent administration of brain-derived neurotrophic factor (BDNF) ameliorates glucose metabolism and prevents pancreatic exhaustion in diabetic mice. J Biosci Bioeng 2008; 105: 395402. doi: $10.1263 /$ jbb. 105.395 
21. de la Monte S, Wands JR. Alzheimer's disease is type 3 diabetes - evidence reviewed. J Diabetes Sci Technol 2008; 2: 1101-1113.

22. Chaldakov GN, Tunçel N, Beltowski J, Fiore M, Ranćić G, Tonchev A, et al Adipoparacrinology: an emerging field in biomedical research. Balkan Med J 2012; 29: 2-9. doi: 10.5152/balkanmedj.2012.022

23. Chaldakov GN, Fiore M, Ghenev PI, Beltowski J, Rancic G, Tunçel N, Aloe L. Triactome: neuro-immune-adipose interactions. Implication in vascular biology. Front Immunol 2014; 5:130. doi: 10.3389/fimmu.2014.00130

24. Chaldakov GN, Fiore M, Tonchev AB, Aloe L. Neuroadipology: a novel component of neuroendocrinology. Cell Biol. Int 2010; 34: 1051-1053.

25. Manni L, Nikolova V, Vyagova D, Chaldakov GN, Aloe L. Reduced plasma levels of NGF and BDNF in patients with acute coronary syndromes. Int J Cardiol 2005; 102:169-171.

26. Ejiri J, Inoue N, Kobayashi S, Shiraki R, Otsui K, Honjo $\mathrm{T}$, et al. Possible role of brain-derived neurotrophic factor in the pathogenesis of coronary artery disease. Circulation 2005; 112: 2114-2120.

27. Sposato V, Manni L, Chaldakov GN, Aloe L. Streptozotocin-induced diabetes is associated with changes in NGF levels in pancreas and brain. Arch Ital Biol 145: 87-97, 2007.

28. Larrieta ME, Vital P, Mendoza-Rodriguez A, Cerbón M, Hiriart M. Nerve growth factor increases in pancreatic beta cells after streptozotocin-induced damage in rats. Exp Biol Med (Maywood) 2006; 231: 396-402.

29. Hoang PT, Park P, Cobb LJ, Paharkova-Vatchkova V, Hakimi M, Cohen P, et al. The neurosurvival factor Humanin inhibits beta-cell apoptosis via signal transducer and activator of transcription 3 activation and delays and ameliorates diabetes in nonobese diabetic mice. Metabolism 2010; 59:343-349. doi: 10.1016/j. metabol.2009.08.001.

30. Mahboobi H, Golmirzaei J, Gan SH, Jalalian M, Jalalian M. Humanin: a possible linkage between Alzheimer's disease and type 2 diabetes. CNS Neurol Disord Drug Targets 2013 Dec 22. [Epub ahead of print].

31. Novelle MG, Contreras C, Romero-Picó A, López M, Diéguez C. Irisin, two years later. Int J Endocrinol 2013; 2013:746281.

32. Spiegelman BM. Banting Lecture 2012: Regulation of adipogenesis: toward new therapeutics for metabolic disease. Diabetes 2013; 62:1774-1782. doi: 10.2337/ db12-1665.

33. Perry T, Lahiri DK, Chen D, Zhou J, Shaw KT, Egan JM, et al. A novel neurotrophic property of glucagon-like peptide 1: a promoter of nerve growth factor-mediated differentiation in PC12 cells. J Pharmacol Exp Ther 2002; 300:958-966.

34. Li L. Is glucagon-like peptide-1, an agent treating diabetes, a new hope for Alzheimer's disease? Neurosci Bull 2007; 23: 58-65. doi: 10.1007/s12264-007-0009-y
35. Prior M, Dargusch R, Ehren JL, Chiruta C, Schubert D. The neurotrophic compound J147 reverses cognitive impairment aged Alzheimer's disease mice. Alzheimers Res Ther 2013; 5: 25. doi: 10.1186/alzrt179

36. Ferenz KB, Rose K, König S, Krieglstein J. ATP-NGFcomplex, but not NGF, is the neuroprotective ligand. Neurochem Int 2011; 59: 989-995. doi: 10.1016/j. neuint.2011.08.020

37. Liu J, Li JD, Lu J, Xing J, Li J. Contribution of nerve growth factor to upregulation of $\mathrm{P}_{2} \mathrm{X}_{3}$ expression in DRG neurons of rats with femoral artery occlusion. Am J Physiol Heart Circ Physiol 2011; 301: H1070-H1079 doi: 10.1152/ajpheart.00188.2011

38. Yoo DY, Kim W, Nam SM, Yoo KY, Lee CH, Choi JH, Won MH, Hwang IK, Yoon YS. Reduced cell proliferation and neuroblast differentiation in the dentate gyrus of high fat diet-fed mice are ameliorated by metformin and glimepiride treatment. Neurochem Res 2011; 36: 2401-2408. doi: 10.1007/s11064-0110566-3

39. Hernández-Pedro N, Granados-Soto V, Ordoñez G, Pineda B, Rangel-López E, Salazar-Ramiro A, et al. Vitamin A increases nerve growth factor and retinoic acid receptor beta and improves diabetic neuropathy in rats. Trans Res 2014; S1931-5244(14). doi: 10.1016/j. trsl.2014.04.002

40. Rabe T, Shamsi F, Mansouri A. The roles of microRNAs in pancreas development and regeneration. Biomed Rev 2013; 24: 57-65.

41. Mortuza R, Feng B, Chakrabarti S. miR-195 regulates SIRT1-mediated changes in diabetic retinopathy. Diabetologia 2014; 57:1037-1046. doi: 10.1007/s00125-014 -3197-9.

42. Cyr NE, Steger JS, Toorie AM, Yang JZ, Stuart R, Nillni EA. Central Sirt1 regulates body weight and energy expenditure along with the POMC-derived peptide $\alpha-\mathrm{MSH}$ and the processing enzyme CPE production in diet-induced obesity male rats. Endocrinology 2014 Apr 28: en20131998.

43. Iacobellis G, Di Gioia C, Petramala L, Chiappetta C, Serra V, Zinnamosca L, et al. Brown fat expresses adiponectin in humans. Int J Endocrinol 2013; 2013:126751. doi: 10.1155/2013/126751.

44. Tan BK, Adya R, Randeva HS. Omentin: a novel link between inflammation, diabesity, and cardiovascular disease. Trends Cardiovasc Med 2010; 20:143-148. doi: 10.1016/j.tcm.2010.12.002.

45. Castan-Laurell I, Dray C, Attané C, Duparc T, Knauf C, Valet P. Apelin, diabetes, and obesity. Endocrine 2011; 40:1-9. doi: 10.1007/s12020-011-9507-9.

46. Wang GX, Cho KW, Uhm M, Hu CR, Li S, Cozacov Z, et al. Otopetrin 1 protects mice from obesity-associated metabolic dysfunction through attenuating adipose tissue inflammation. . Diabetes 2013 Dec 30. [Epub ahead of print]

47. Karatzas A, Katsanos K, Lilis I, Papadaki H, Kitrou $\mathrm{P}$, Lecht S, et al. NGF promotes hemodynamic re- 
covery in a rabbit hindlimb ischemic model through trkA- and VEGFR2-dependent pathways. I Cardiovasc Pharmacol 2013; 62:270-277. doi: 10.1097/ FJC.0b013e3182982de7.

48. Aloe L, Tirassa P, Lambiase A. The topical application of nerve growth factor as a pharmacological tool for human corneal and skin ulcers. Pharmacol Res 2008; 57: 253-258. doi: 10.1016/j.phrs.2008.01.010

49. Schäffler A, Schölmerich J, Buechler C. The role of "adipotrophins" and the clinical importance of a potential hypothalamic-pituitary-adipose axis. Nat Clin Pract Endocrinol Metab 2006; 2:374-383.

50. Hausman GJ, Barb CR, Dean RG. Patterns of gene expression in pig adipose tissue: insulin-like growth factor system proteins, neuropeptide Y (NPY), NPY receptors, neurotrophic factors and other secreted factors. Domest Anim Endocrinol 2008;35:24-34.

51. Rao AA. Views and opinion on BDNF as a target for diabetic cognitive dysfunction. Bioinformation 2013; 9: 551-554. doi: 10.6026/97320630009551

52. Meek TH, Wisse BE, Thaler JP, Guyenet SJ, Matsen ME, Fischer JD, et al. BDNF action in the brain attenuates diabetic hyperglycemia via insulin-independent inhibition of hepatic glucose production. Diabetes 2013; 62: 1512-1518. doi: $10.2337 / \mathrm{db} 12-0837$

53. Byerly MS, Swanson RD, Semsarzadeh NN, McCulloh PS, Kwon K, Aja S, et al. Identification of hypothalamic neuron-derived neurotrophic factor as a novel factor modulating appetite. Am J Physiol Regul Integr Comp Physiol 2013; 304: R1085-R1095. doi: 10.1152/ ajpregu.00368.2012

54. Kostopoulos CG, Spiroglou SG, Varakis JN, Apostolakis E, Papadaki HH. Adiponectin/T-cadherin and apelin/ APJ expression in human arteries and periadventitial fat: implication of local adipokine signaling in atherosclerosis? Cardiovasc Pathol 2014; doi: org/10.1016/j. carpath.2014.02.003

55. Bouckenooghe T, Sisino G, Aurientis S, Chinetti-Gbaguidi G, Kerr-Conte J, Staels B, , et al. Adipose tissue macrophages (ATM) of obese patients are releasing increased levels of prolactin during an inflammatory challenge: a role for prolactin in diabesity? Biochim Biophys Acta 2014; 1842:584-593. doi: 10.1016/j. bbadis.2013.12.005.
56. Benga G, Popescu O,Pop VI,Holmes RP.p-(Chloromercuri) benzenesulfonate binding by membrane proteins and the inhibition of water transport in human erythrocytes. Biochemistry 1986; 25: 1535-1538. doi:10.1021/bi00355a011

57. Benga G. Aquaporin-7 and adipose tissue. Biomed Rev 2006; 17: 102-108.

58. Frühbeck G, Catalan V, Gomes-Ambrosi J, Rodriguez A. Aquaporin-7 and glycerol permeability as novel obesity drugtraget pathwas. Trends Pharmacol Sci 2006; 27: 345-347.

59. Jackson HM, Soto I, Graham LC, Carter GW, Howell GR. Clustering of transcriptional profiles identifies changes to insulin signaling as an early event in a mouse model of Alzheimer's disease. BMC Genomics 2013 14:831. doi:10.1186/1471-2164-14-831

60. Luchsinger JA, Mayeux R. Adiposity and Alzheimer's disease. Curr Alzheimer Res 2007; 4: 127-134. doi: 10.2174/156720507780362100

61. Naderali EK, Ratcliffe SH, Dale MC. Review: obesity and Alzheimer's disease: a link between body weight and cognitive function in old age. Am J Alzheimers Dis Other Demen 2009; 24:445-449.

62. Frisardi V, Solfrizzi V, Seripa D, Capurso C, Santamato A, Sancarlo D, et al. Metabolic-cognitive syndrome: A cross-talk between metabolic syndrome and Alzheimer's disease. Ageing Res Rev 2010; 9:399-417.

63. O’Neill C, Kiely AP, Coakley MF, Manning S, LongSmith CM. Insulin and IGF-1 signalling: longevity, protein homoeostasis and Alzheimer's disease. Biochem Soc Trans 2012; 40:721-727.

64. de la Monte SM. Brain insulin resistance and deficiency as therapeutic targets in Alzheimer's disease. Curr Alzheimer Res 2012; 9:35-66.

65. Hildreth KL, Van Pelt RE, Schwartz RS. Obesity, insulin resistance, and Alzheimer's disease. Obesity 2012; 20:1549-1557.

66. Passaro A, Dalla Nora E, Morieri ML, Soavi C, Sanz JM, Zurlo A, et al. Brain-derived neurotrophic factor plasma levels: Relationship with dementia and diabetes in the elderly population. J Gerontol A Biol Sci Med Sci 2014 Mar 12. [Epub ahead of print]

67. Li Z, Zhang C, Fan J, Yuan C, Huang J, Chen J, et al. Brain-derived neurotrophic factor levels and bipolar disorder in patients in their first depressive episode: 3-year prospective longitudinal study. Br J Psychiatry 2014; doi:10.1192/bjp.bp.113.134064 